\title{
Immune haemolytic anaemia and nomifensine treatment in north west England 1984-85: report of six
}

\section{cases}

\author{
VANESSA JOAN MARTLEW \\ From the Regional Transfusion Centre, Plymouth Grove, Manchester
}

SUMMARY Nomifensine, an antidepressant used for eight years in Britain, was particularly popular in the north west of England. Haemolytic anaemia was recognised as a rare side effect, but in 1984 a cluster of six cases was referred to the North West Regional Transfusion Centre, reflecting an incidence of $0.006 \%$. These were collected within 18 months and showed variable serological features, indicating that antibodies associated with nomifensine treatment are neither rare nor of one particular type. The accumulation of this and similar data contributed to its withdrawal from the British market in January, 1986.

Nomifensine was introduced in 1977 as an antidepressant and was widely used in Britain for more than eight years. Haemolytic anaemia had for some years been recognised as an uncommon side effect of intermittent treatment and overdosage with nomifensine. ${ }^{12}$ In a study by Salama and MuellerEckhardt $^{3}$ a remarkable heterogeneity of antibody response in only 19 patients from Europe and South Africa over three years was reported. Their small number of cases is consistent with a rare phenomenon. This paper reports six women with haemolysis complicating nomifensine treatment over 18 months who had been referred to the North Western Regional Transfusion Centre. The prescribing area described by the manufacturer, Hoechst Pharmaceutical, as "north western" includes the mersey and north western region. The highest numbers of prescriptions for nomifensine in the United Kingdom were written in the north west in recent years. The recognition of acute haemolysis as a common complication of treatment with nomifensine in the north west contributed to its withdrawal at source in January, 1986.

\section{Case reports}

CASE 1

An obese 43 year old woman presented with depression in March, 1983. Nomifensine $50 \mathrm{mg}$ daily was prescribed to good effect. After a lapse in treatment of

Accepted for publication 14 May 1986 some months this was reintroduced at a dose of $100 \mathrm{mg}$ daily in March, 1984. The only other medications were dothiepin and clorazepate, which were prescribed throughout. Ten days after resuming nomifensine she developed severe loin pain. A further episode two days later precipitated admission to hospital.

On arrival she was rousable but confused, her blood pressure was $90 / 60 \mathrm{~mm} \mathrm{Hg}$, pulse 140 /minute regular, and she did not have a fever. The abdomen was diffusely tender and there were ecchymoses on the flanks. She was pale, slightly jaundiced, and her urine was dark in colour. Her haemoglobin concentration was $8.4 \mathrm{~g} / \mathrm{dl}$, she was thrombocytopenic (platelets 100 $\left.\times 10^{9} / 1\right)$, and there were nucleated red cells in the blood film. Bilirubin concentration was $500 \mathrm{mmol} / \mathrm{l}$, and liver enzymes, blood urea, and electrolytes yielded normal results. Free haemoglobin was detected in the urine. Fibrinogen degradation products were not increased. The direct antiglobulin test was positive and cold agglutinins were reported in the blood film. There was difficulty in crossmatching blood but one unit of $\mathrm{O}$ negative blood was given as an emergency measure and her blood pressure stabilised at $120 / 80 \mathrm{~mm} \mathrm{Hg}$ thereafter.

Over the 24 hours oliguria was noted, but subsequently urine output was promoted with frusemide. The haemoglobin concentration fell from $12.7 \mathrm{~g} / \mathrm{dl}$ after transfusion to $7.8 \mathrm{~g} / \mathrm{dl}$ within 48 hours in the absence of bleeding. Her blood urea and creatinine concentrations rose steadily from $49 \mathrm{mmol} / 1$ on day two to $997 \mu \mathrm{mol} / \mathrm{l}$ on day nine. Peritoneal dialysis was 
used intermittently for three weeks, and high dose steroids were given for five days.

Further investigations at the Regional Transfusion Centre attributed the crossmatching difficulties to a cold agglutinin with a wide thermal range. This was shown using red cells incubated under various conditions, including saline at $16^{\circ} \mathrm{C}$, saline at $37^{\circ} \mathrm{C}$, serum albumin at $37^{\circ} \mathrm{C}$, and enzyme treated cells both at $16^{\circ} \mathrm{C}$ and $37^{\circ} \mathrm{C}$. The indirect antiglobulin test showed an IgM antibody with complement fixation, and the direct antiglobulin test was also strongly positive, fixing complement. The Donath-Landsteiner test yielded negative results. There was some indication in the acute phase of anti-I specificity, which disappeared within six weeks.

\section{CASE 2}

A 28 year old housewife was delivered in 1984 of a healthy infant. Her pregnancy was complicated at 36 weeks by a psychotic disturbance for which she received chlorpromazine. One month later she was delivered of a normal baby and discharged after 48 hours for outpatient psychiatric follow up. After 10 days she became depressed and her treatment was changed to thioridazine and nomifensine. Interestingly, a psychotic illness had complicated her first pregnancy in 1980 and was similarly relieved by chlorpromazine. In 1983 nomifensine was prescribed for depression to good effect but was discontinued when she wished to have another baby.

Three weeks after delivery she was admitted urgently to hospital with a short history of pain in the lower chest and upper abdomen. There was associated nausea, and within a short time the epigastric pain subsided and moved to her back. On examination she was pale, with a sinus tachycardia and a blood pressure of $100 / 60 \mathrm{~mm} \mathrm{Hg}$. She was locally tender at the site of the pain, but there was no guarding or rebound tenderness, and there was no evidence of recent blood loss. Although a normal haemoglobin concentration had been recorded throughout her pregnancy, and was $12.4 \mathrm{~g} / \mathrm{dl}$ on admission, two days after delivery, three weeks later it had fallen to $5.7 \mathrm{~g} / \mathrm{dl}$, and her blood film showed massive autoagglutination with a "shift to the left." Free haemoglobin was present in plasma and serum. Haptoglobins were reduced and the direct antiglobulin test was strongly positive. Haemoglobinuria was not detected. There was a rise in the aspartate transaminase activity to $130 \mathrm{IU} / \mathrm{ml}$, but otherwise her renal and liver function tests yielded normal results. There was no serological evidence of a collagen disorder. Blood requested for crossmatch was found to be incompatible.

Subsequent investigations at the Regional Transfusion Centre showed that the direct antiglobulin test was positive with complement present on her red cells. There was a powerful non-specific cold autoagglutinin with extended thermal range. This was shown using red cells incubated under various conditions, including saline at $16^{\circ} \mathrm{C}$, saline at $37^{\circ} \mathrm{C}$, serum albumin and enzyme treated cells. The indirect antiglobulin test showed some fixation of complement. Once her drugs had been discontinued, she made a very rapid recovery. Her pain disappeared within a few hours and her haemoglobin concentration was restored to normal within 48 hours without transfusion. The serum antibodies disappeared within two weeks, but the direct Coombs test remained weakly positive for three months.

\section{CASE 3}

A 27 year old woman was admitted with a history of collapse, vomiting, and four days' haematuria, which had started two weeks after treatment with nomifensine had been prescribed for depression. She had also experienced some numbness in both legs but there were no abnormal neurological findings to explain this symptom. Two years previously she had received a course of nomifensine for a depressive illness. On admission her haemoglobin concentration was $3.2 \mathrm{~g} / \mathrm{dl}$ and the film showed widespread agglutination that persisted when her blood was spread a $37^{\circ} \mathrm{C}$. The reticulocyte count was $3 \%$ and Schumm' test was positive, indicating that methaemalbumer was present in the plasma. Massive intravascular hae molysis and impending renal failure was diagnosed: Blood was requested for transfusion, but there was difficulty in grouping and all units were found to be incompatible. Subsequent investigation by the Regional Transfusion Centre showed she was $O$ Rhesus (D) positive with a strong non-specific cold autoagglutinin. There was also an antibody acting in the indirect antiglobulin test at $37^{\circ} \mathrm{C}$ using an anti-IgG reagent. This showed some rhesus specificity-that is, anti-E + anti-c, which was also shown using papainised cells. Her direct antiglobulin test was positive with both anticomplement and antiIgG reagents. She was transfused at once with four units of group $\mathrm{O}$ rhesus (D) negative red cells before her group was established because of her poor clinical condition. These were packed hard and plasma was removed to reduce complement. The drugs were discontinued and her haemoglobin concentration rose to $11.4 \mathrm{~g} / \mathrm{dl}$ within a week. Renal function was not impaired.

\section{CASE 4}

A 74 year old woman presented in 1983 with macrocytic anaemia. Twelve months earlier she had been admitted to hospital with an episode of abdominal pain and jaundice, which had been attributed to acute

.


cholecystitis. In 1982 nomifensine, $25 \mathrm{mg}$ twice daily was prescribed for a depressive illness. The dose was halved after six weeks. Laboratory investigation in 1983 had shown a haemoglobin concentration of $8.5 \mathrm{~g} / \mathrm{dl}$, with a mean corpuscular volume of $124 \mathrm{fl}$ and $15 \%$ reticulocytes. The direct antiglobulin test was positive with IgG bound to the patient's cells until 18 months after the acute episode. A heat eluate indicated no specificity and no antibodies were detected in her serum. White cells and platelets were normally represented. A blood film showed polychromasia with anisocytosis and some spherocytes. Biochemical abnormalities included a blood urea of $16.4 \mathrm{mmol} / 1$, serum creatinine concentration of $134 \mathrm{mmol} / \mathrm{l}$, and serum aspartate transaminase activity of $180 \mathrm{IU} / \mathrm{ml}$. Antinuclear factors were present at a titre of $1 / 300$. Total immunoglobulins were normal, and liver antibodies absent. Nomifensine was discontinued at her first visit. A month later her haemoglobin concentration was $10.8 \mathrm{~g} / \mathrm{dl}$ and in eight weeks it was $12.9 \mathrm{~g} / \mathrm{dl}$. Within three months the antinuclear factor (IgG) had fallen to $1 / 100$ and at six months it was no longer detected. Fifteen months later in 1984 antinuclear factors were reported again at $1 / 1000$, but anaemia did not recur. She had shown some features of systemic lupus erythematosis. Her presentation with an IgG type of autoimmune haemolytic anaemia, which was related to nomifensine, improved when the drug was withdrawn but its role in the aetiology of the falling haemoglobin is not clear.

\section{CASE 5}

A 50 year old clerical officer was referred to a consultant physician in 1983 for investigation of flatulence and epigastric discomfort associated with a weight loss of two stones. Twelve months earlier she had been depressed and had been prescribed nomifensine and clobazam. Endoscopy gave a negative result but a fall in haemoglobin concentration was observed, $10 \mathrm{~g} / \mathrm{dl}$ to $8.4 \mathrm{~g} / \mathrm{dl}$ over a period of one week. The mean corpuscular volume was $104 \mathrm{fl}$. Her white cells and platelet counts were normal, but the film showed polychromasia and spherocytes. The direct antiglobulin test was strongly positive, with IgG bound to red cells. Apart from a slight increase in aspartate transaminase activity to $57 \mathrm{IU} / \mathrm{ml}$, all other biochemical results yielded normal results. Nomifensine was discontinued, and a reducing course of steroid treatment was introduced, starting with prednisolone, $80 \mathrm{mg}$ daily. Within a week her haemoglobin concentration has risen to $10.4 \mathrm{~g} / \mathrm{dl}$ and her progress was maintained.

Serological investigation by the Regional Transfusion Centre showed an avid autoantibody with no apparent specificity acting at $37^{\circ} \mathrm{C}$ in serum albumin and by the indirect antiglobulin technique, with both
IgG and anti-C3d. Some rhesus specificity with antice was shown, using papainised cells at $37^{\circ} \mathrm{C}$. The IgG bound to red cells was confirmed by a direct antiglobulin test, and an eluate prepared from these cells contained an antibody with similar properties to those found in serum.

The antibody had disappeared from the serum within three months, and the direct antiglobulin test was only weakly positive four months later, with anticomplement reagents.

\section{CASE 6}

A 28 year old woman with long standing rheumatoid disease was admitted to hospital in 1985 for elective hysterectomy. Her medication included primolut $\mathrm{N}$, apisate, pentazocine, feldene, dalmane, and nomifensine. She had previously received nomifensine for symptoms of depression. She had not had a pregnancy but had received a blood transfusion within the last year, and on routine preoperative crossmatching she was found to be group $\mathrm{O}$ rhesus (D) positive with a positive direct antiglobulin test. IgG molecules were detected on her red cells in large quantities by an antiglobulin method using radiolabelled anti-IgG reagent. An eluate showed anti-C and anti-e specificity similar to that detected in the serum acting with enzyme treated cells and serum albumen at $37^{\circ} \mathrm{C}$. Although her haemoglobin concentration was normal, there were spherocytes in her peripheral blood and $5 \%$ reticulocytes. Her lactate dehydrogenase activity was increased. Nomifensine was discontinued at once but other drugs were continued and the number of IgG molecules per cell reduced considerably over the next few weeks, although their specificity persisted in the absence of haemolysis. Complement was not detected on her cells.

\section{Serological follow up (cases 1, 2, and 5)}

When the clinical conditions of these patients stabilised, investigations were repeated until antibody was no longer present in serum. This occurred after three months in case 1 , six months in case 2, and later in case 5 . When the direct antiglobulin test showed that anti-C4d only remained on the red cells, using pre-transfusion stored serum as a positive control and saline as a negative control, donor ABO compatible papainated cells were incubated with nomifensine in vitro. Sera from cases 1 and 2 were found again to fix complement on exposure to the drug according to method of Habibi. ${ }^{4}$ It was concluded that these patients produced a cold agglutinin in response to nomifensine. Case 5 failed to sensitise donor cells in this way on re-exposure and the three others have not been thus investigated at the time of writing, because their serum antibodies persisted. 


\section{Discussion}

Immune haemolytic anaemia in association with nomifensine treatment in prescribed doses has hitherto been reported as a rare occurrence. ${ }^{15}$ A series of only 19 patients was collected over three years from Europe and South Africa and described by Salama $e t$ al in $1985 .^{3}$ The prescription of nomifensine in the north western area represented about $20 \%$ of that for the whole of the United Kingdom in the two years before its withdrawal, although the population is less than $10 \%$ of the total. It might, therefore, be expected that the incidence of side effects should be disproportionately high locally.

Since March, 1984, haemolysis has been shown in six users of nomifensine in the north west region over a period of only 18 months. The heterogeneity of serological findings here concurs with those of the 1985 report from Salama et $a l,{ }^{3}$ who reported complement fixation in association with IgM over an extended thermal range; IgG bound with and without rhesus specificity at $37^{\circ} \mathrm{C}$, with combinations of these features in users of nomifensine. The use of metabolites of the drug increased the incidence of positive serological findings in their series. In all their cases there was evidence of complement activation, but this was absent in two of ours, cases 4 and 6 . Each of our patients had a positive direct antiglobulin test-two using anti-IgM and complement, three binding mainly IgG, and one binding both IgM with complement fixation and IgG with specificity anti-ce. Those with a strong complement fixing antibody presented with features of a sudden severe intravascular haemolysis, presumably as a result of an "innocent bystander" mechanism. The onset was so acute that upper abdominal pain and shock preceded haemoglobinuria by some hours. Such patients present a diagnostic problem in the short term as they may appear to have an intra-abdominal surgical problem requiring urgent laparotomy. Those with warm IgG antibodies alone had a less dramatic presentation with a slow fall in haemoglobin concentration and mild jaundice. Our six patients were all women. This concurs with the report of 19 similar cases by Salama et al, which included only one man.

Each of the six was receiving her second course of nomifensine. Prior exposure as a feature of nomifensine sensitivity was recorded first by Bournerias and Habibi' in 1979 and is a typical feature of the history in most cases, as is the reversal of the direct antiglobulin test to negative over a variable period of time (usually months) after the drug is discontinued. All our patients had raised serum transaminase activities during the haemolytic episode, and one had renal failure requiring dialysis for some weeks.

The three "cold" antibodies detected were all active at $37^{\circ} \mathrm{C}$ to account for symptoms in vivo, although the complement fixing antibodies were more avid at lower temperatures. In the first two cases antibodies disappeared from the serum within six weeks. When the direct antiglobulin was once more negative serum was incubated with nomifensine and papainised cells in vitro. Agglutination with an anticomplementary reagent indicated persistence of individual sensitivity to the drug in cases 1 and 2. The effect was greater with $\mathrm{ABO}$ matched cells. Using the method of Habibi et $a l,{ }^{4}$ serum from one patient with an IgG antibody (case 5) was similarly treated with negative results. Cases 3, 4, and 6 have not been investigated in this manner at the time of writing because the antiglobulin tests remained positive.

This series of six patients was collected in a small area where nomifensine was a popular choice for depression over a short period of time. Forty five thousand one hundred and eighty and 47250 prescriptions, respectively, in 1984 and 1985, were written in the north west. Renal failure, as described in case 1 , is a well recognised complication of haemolysis and may occur independently with this drug, and a fatality was reported by Sokol et al. ${ }^{2}$ In the light of these sequelae, which may no longer be regarded as rare, nomifensine was withdrawn from use.

I thank my colleagues Drs Turck, Wolstenholme Platt, and Richmond, who kindly referred thêे patients for serological investigation supervised b. Mr Riches and Mrs Laycock at the Regional Transfusion Centre, and Mrs Pamela Soar, who typed the manuscript.

\section{References}

1 Lyloff K, Jersild-Bacher T, Slot O. Massive intravascular haemolysis during treatment with nomifensine. Lancet 1982;ii:41.

2 Sokol RJ, Hewitt S, Booker DJ, Stamps R, Taylor M, Stewart R. Fatal immune haemolysis associated with nomifensine. $\mathrm{Br}$ Med $J$ 1985;291:311-12.

3 Salama A, Mueller-Eckhardt C. The role of metabolite-specific antibodies in nomifensine dependent immune haemolytic $\mathrm{O}$ anaemia. New Engl J Med 1985;313:469-74.

4 Habibi B, Carltron JP, Bretagne M, Rouger P, Salmon C. Antinomifensine antibody causing immune haemolytic anaemia and renal failure. Vox Sang 1981;40:79-84.

5 Prescott LF, Illingsworth RN, Critchley JAJH, Frazer I, Stirling o MI. Acute haemolysis and renal failure after nomifensine over- $N$ dose. Br Med J 1980;281:1392-3.

6 Bournerias F, Habibi B. Nomifensine induced immune hae- $\omega$ molytic anaemia and impaired renal function. Lancet $\bar{\sigma}$ 1979;ii:95-6.

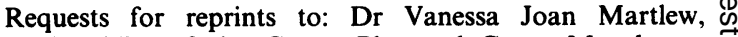
Regional Transfusion Centre, Plymouth Grove, Manchester M139LL, England. 